\title{
THE END GAME: THE MARKETISATION AND PRIVATISATION OF CHILDREN'S SOCIAL WORK AND CHILD PROTECTION
}

\begin{abstract}
There is a long history of voluntary and other organisations, along with the state, providing social services for children in England. But crucial assessments and decision-making about the care and protection of children have been undertaken by local authorities within the context of democratic accountability and transparency. This is changing. The government is opening up children's social work services, including child protection investigations and assessments, decisions about initiating care proceedings in the courts to have children removed from their families, and decisions where children should then live, to the market and to the private sector with companies such as G4S and Serco expanding into children's social services. Nowhere else in the world are profit-driven companies given these powers. This paper traces how this radical change is moving forward at pace.
\end{abstract}

\section{KEY WORDS}

Child Protection

Social Work

Social Policy

Children in Care

Organisation

\section{MAIN TEXT}

This paper charts the recent developments in marketising and privatising child protection investigations and assessments, and children's social work case management, and placing them outside the public sector. The journey of marketising and privatising children's social work has been well charted and critiqued (see, for example, Harris, 2005; Garrett, 2009), and can also be located within a wider political attack on social work (Garrett, 2015). The pace of this journey has accelerated during the past two years.

The concerns about opening up to the market children's social work, including child protection decision-making and decisions about where children subject to care orders should live, are threefold. Firstly, outsourcing these social work services from local authorities will remove local democratic oversight and direct accountability for the services, with the accountability only to be through contract management and with the services themselves not transparent and open to public scrutiny. This will be the position whether the contracted out services are owned and provided by not-for-profit or forprofit commercial organisations. Secondly, the government is allowing that profit-focussed organisations be allowed to provide these services, intruding into families and taking major decisions about children, albeit these commercial companies will have to set-up apparently not-for-profit subsidiaries. Thirdly, it is intended that the organisations contracted to provide the services will not themselves be regulated, registered or inspected.

\section{THE PAST POLITICAL AND POLICY JOURNEY}

The Conservative and Liberal Democrat government of 2010-2015 had undertaken a major dismantling of the welfare state. It pursued an agenda set in the 1980s by the governments of Margaret Thatcher and continued throughout the late 1990s and early 2000s by Tony Blair's 'New Labour'. It was 'New Labour', for example, that introduced academy schools and NHS foundation 
trusts, escalated the private finance initiative (PFI) as the means of providing capital funding for public services, and cut back on regulatory requirements as a part of making public services ripe and attractive for the market place and privatisation. Over recent years, along with housing and public utilities such as water, gas, electricity, housing and rail services, other very personal services such as prisons, probation, policing, schools, health services and welfare benefits assessments and delivery, have all been increasingly opened up to the market place (Meek, 2014).

Companies, often owned outside the United Kingdom by foreign governments or venture capitalists looking to make quick profits, and with no affinity with the services they now own and control and no commitment to the communities using the services, have had increasing opportunities to capture and exploit for share holder and owner economic gain the availability of public funding for services they now provide through government contracts. And these companies have become huge. G4S, Serco, Capita, and the big four accountancy firms (KPMG, Ernst and Young; Price-Waterhouse Coopers $\mathrm{PwC}$, and Deloitte) and others have profited from out-sourced government contracts and public expenditure. Like the banks they have become too big to fail, as can be seen from the debacle of G4S not fulfilling its contract to provide security at the 2014 London Olympics and its overcharging for the tagging of offenders, but still being awarded further government contracts at the same time investigations were underway into its recent major failings (Jones, 2014, p 201).

\section{THE POLICY PROMISE}

All of the privatisation progress so far is only a few steps on the journey to what is intended and promised by the Conservatives. The stated plan is that by 2020 there should be a dramatic further erosion of public expenditure and public services with it reported that this reduction will take the state and services back to the pre-welfare state levels of the 1930s (Office for Budget Responsibility, 2014).

But surely there are some state responsibilities and services which should never be exposed to the market with the overwhelming motive and focus of those providing the services being profit. These services then become insecure and vulnerable. Firstly, in the drive for profit costs and corners are cut. Secondly, if the profit is not quick or large enough the providers close down the service and cash in what profit they have already made, leaving those who are dependent on the service stranded. One responsibility which has been seen to-date to be too important to expose to the machinations of the market has been the safety and welfare of very vulnerable children.

\section{THE PROGRESS IN BUILDING THE PLATFORM FOR PRIVATISING CHILDREN'S SOCIAL SERVICES}

But in line with the philosophy of New Labour, Blairism and the Third Way (Giddens, 1988; see also Le Grand, 2003) this started to change. Pilots were introduced so that social work services and decisions about very vulnerable children could be provided outside of local authorities. These independent 'social work practices' were to be restricted to the case management and decisionmaking about looked after children and care leavers. Their early champion, Julian Le Grand, is still influential and active today, advising the government on how to tackle local authorities, such as Doncaster and Birmingham, which are seen to be failing to provide adequate child protection services.

In 2007 soon after independent social work practices were first mooted it was stated that:

"Social work practices are the brainchild of Julian Le Grand, a former Downing Street advisor and key architect of Labour's public service reforms and a professor of social policy at the London School of Economics. As the man who introduced choice and competition into health care and education, he is now keen to bring the same ethos to social work for looked after children" (Ahmed, 2007).

Le Grand argued that: 
"SWPs [social work practices] could be forms of social enterprise, such as a professional partnership or voluntary sector organisation, or private sector firms of various types from share-holder owned corporations to small owner-operated businesses. The Group's preferred model is the professional partnership which is a form of an employee owned company (EOC): an enterprise where the majority, or all, of the share capital is owned by the employees themselves" (Le Grand, 2007, p 7).

It was in the 2006 green paper 'Care Matters' that the Labour government introduced the concept of independent social work practices:

"A practice would be an autonomous organisation, whether a voluntary or community sector organisation, a social enterprise or a private business - similar to a GP practice - registered with the Commission for Social Care Inspection and responsible for employing social workers" (Department for Education and Skills, 2006).

When the concept of social work practices was first introduced there were conflicting views about whether they would benefit those assisted by social workers and be a positive development for social workers themselves. Social work practices were presented as allowing more professional autonomy for social workers outside of the managerialism, bureaucratisation and proceduralisation which had become prevalent within local authority children's social services (Le Grand, 2007 ) - in large part a consequence of requirements set by central government (Barber, 2007). Conversely there were concerns that, firstly, this could be a route to the marketisation and privatisation of social work (Garrett, 2008; 2010; Cardy, 2010) , and, secondly, it could undermine local authorities' accountability as 'corporate parents' for children and young people in care and for care leavers, and that money would be better spent improving councils' services (Ahmed, 2007).

Between December 2009 and May 2010 five pilot independent social work practices (SWPs) were initiated providing case management for looked after children and for care leavers. The evaluation of these pilots hardly produced a fulsome endorsement of the model:

"It is difficult to see how SWPs would function were local authorities to move all their children's services out into SWPs as some local authorities are reportedly contemplating. In the case of such a scenario, some of the core functions and expertise of the local authorities essential for the success of SWPs would be lost" (Stanley et al, 2012, p iii).

The model of social worker owned and controlled small independent social work practices was found, therefore, to lack resilience and not able to stand-alone. The researchers specifically noted their concern that some local authorities might be contemplating moving all of their children's services outside of the council when these services would then be potentially isolated from the other services and responsibilities within the council.

The preferred model of Le Grand was not seen as sustainable, but the door had been opened to other means for taking children's social work case management outside of local authorities as the timelimited regulatory change -within Part 1 of the 2008 Children and Young Persons Act - also allowed 'bodies corporate', which could included 'private sector firms of various types" to take on these contracted out responsibilities.

The findings of the evaluation of the children's social work practices were reinforced when independent social work practices were then piloted for social work with adults (SWPwA):

"To a great extent the work of the SWPwA remained tied to that of the commissioning local authority ... Beyond assessment and care management few of the pilots developed innovative social work interventions such as those which might draw on their therapeutic or counselling skills but some expressed ambitions to do so ... Over the course of the pilots, significantly 
more pilot practitioners felt they were not spending enough time working directly with adults in need of care" (Manthorpe et al, 2014).

But despite the reservations from the evaluations of social work practices, the coalition government in 2013 committed itself (HM Government, 2013a) to continuing what the previous Labour government had piloted. It was explicit that this was to include 'private social work providers'. It, however, also intended to take it a further step.

The coalition government had intended that the social work practices should not be required to be registered or inspected by Ofsted, but at the time it did what was described as a 'u-turn' following concerns raised in the House of Lords (Hayes, 2013). The coalition government's ambition in 2013, however, to move ahead with the deregulation of children's social services outside of local authorities was not abandoned. For example, there was a report headed 'Ofsted to shift children's centres inspections from providers to council" based on comments from Elisabeth Truss, the childcare minister (McCardle, 2014).

\section{PICKING UP THE PRIVATISATION PACE}

Over a seven year between 2006 and 2013, therefore, there was the development of independent social work practices taking decisions about the lives of children and young people in care and leaving care. These organisations could be profit or not-for-profit organisations. Moving much more quickly than the seven years it took to introduce independent social work practices for children in care, during 2014 the coalition government moved ahead to open up almost all children's social work services to the market and potential privatisation. There were to be only two exceptions - independent reviewing officers (IROs) for children in care and adoption services.

For all other children's social services the government proposed in April 2014 that they be allowed to be contracted to any type of organisation. Local authorities could decide to contract out all the services or the government could direct that the services be provided outside of the local authority. It has already taken this decision for Doncaster and Slough.

This radical and fundamental change was to be delivered not through a new Act of Parliament but through a change in regulation, and unless there is formal opposition within Parliament to what is proposed, it moves ahead with little political, and usually little media and therefore public, attention. This is what has been happening since April 2014.

The consultation period allowed by the government for consideration about the opening up of children's social (work) services to the market and private profit-making sector was particularly short. The consultation was launched in 2014 just before the Easter holidays and ran for only six weeks and itself became a cause of complaint. However, despite the short time given to the consultation there was overwhelming opposition to what was proposed.

After 38 senior social work academics and others wrote a letter to The Guardian it became The Guardian's front page story (Butler, 2014a) and was then covered by other media. Within days over 70,000 people signed a 38 Degrees petition opposing the government's plans, and organisations including Children England, the British Association of Social Workers, the College of Social Work, the Children's Commissioner for England, the Association of Directors of Children Services, and Unison, issued statements and gave responses expressing their concerns and opposition to the government's proposals. The government reported that $94 \%$ of over 1300 responses received were opposed to the opening up of children's social (work) services to the private sector.

Later in June the government issued a press release. The headlines the following day were that the government had reflected on the consultation responses and were doing a u-turn. Private sector companies would not be allowed to receive contracts for children's social services. There was general acclaim that G4S, Serco and others who built their businesses on government contracts would not be 
undertaking child protection investigations and taking crucial decisions about children and families. In late 2014 and early 2015 this is still understood by some as being the position (Cleary, 2014; 38 degrees, 2015). Unfortunately this is not so.

When the government did issue its revised draft regulation it still allowed private profit-making companies to be given contracts for all children's social services (except IROs and adoption). They would now be required to set-up a not-for-profit subsidiary to provide the services, but would still be able to generate a profit by the parent company selling its subsidiary management, administration and estates services at whatever cost was determined by the parent company.

\section{THE VIEWS OF OTHERS}

Not all have been opposed to this opening up of children's social (work) services to the market and to the private sector. Firstly, the big national children's voluntary organisations have presented it as a false concern (Turner, 2014), or argued that they might be within a consortium with the private sector (Hayes, 2014a).

Voices in support of the government have included its advisors on children's social services. Sir Martin Narey had been the head of the prison service before becoming the former chief executive of Barnardo's. Private prisons were promoted and established when he led the prison service. In relation to the criticisms and opposition that private companies should be able to get contracts to provide children's social (work) services Narey has said:

"There is, in my mind, no reason why a properly managed private sector organisation - by itself, or more likely, in partnership with a public or voluntary sector provider - could not compete to play a role in child protection ... [and the criticisms are] a sanctimonious dismissal of the morality of the private sector. I've spent all my life in the public and voluntary sectors. But I've never agreed with those who claim a moral superiority over private sector organisations and those who work for them "(Hayes, 2014).

Another advisor to the government who has been described as an outsourcing "champion", and supportive of the private sector becoming involved in child protection, is Alan Wood. A former history teacher and Labour councillor in Camden, he became Hackney's director of children's services. In 2013-2014 he was president of the Association of Directors of Children's Services. Along with Le Grand, he had advised the government on the removal of children's social services from Doncaster Council and what action should be taken regarding children's social services in Birmingham.

Interviewed as the president of the Association of Director of Children's Services Wood described newly qualifying social workers as 'crap' and was described as "unperturbed by government proposals that child protection providers might be charitable arms of for-profit providers" (Butler, 2014b):

" 'I think the idea that Serco or G4S or Virgin are going to come over the hill on a horse and sweep up a whole series of child protection services is complete and utter madness. They are not daft! They are not going to pick business where the level of risk and threat are so bloody serious that it would bankrupt them in five minutes' ... and anyway, he suggests, the issue is ultimately not whether the likes of G4S win a contract, but whether a local authority has access to enough high-quality social workers" (Butler, 2014b).

Mr Wood's "championing" of outsourcing, and being "unperturbed" about private profit-driven companies receiving contracts for children's social work services and decision-making, was not shared by the organisation, the Association of Directors of Children's Services (ADCS), of which he was president and for which he was the senior spokesperson: 
"Decisions taken about a child's life should only ever be based on what is in the best interests of the child as assessed by skilled and qualified social workers and the court system. These decisions cannot, and must not, be subordinate to the pursuit of financial profit. There is a serious risk of perverse financial incentives (direct or indirect) that could potentially distort decisions in individual cases, for example, to intervene or not, to take a child into care or not ... It is clear that government intends that issuing care proceedings will be covered by these proposed changes. ADCS members' view is that the power to remove children and young people, with or without the oversight of the judiciary, is such a fundamental power that it should be retained by the state ... ADCS members are of the view that these proposals create the possibility of complete confusion of accountabilities and potentially risk further fragmentation of the complex collaborative partnerships that characterise children's social care services. Further fragmentation would not be in the best interests of children, young people and families whose access to and engagement with these services must be made as easy as possible" (ADCS, 2014).

As Director of Children's Services in Hackney, one of Wood's senior managers was Isabelle Trowler. She, along with Steve Goodman (who was awarded an OBE in 2014), developed the 'reclaiming social work' model of small units led by a consultant social worker assessing and working with children and families (Goodman and Trowler, 2011). Goodman and Trowler left Hackney Council and established a company, Morning Lane Associates (named after the office location of Hackney Council), to promote and market what became known as the 'Hackney model', selling consultancy to local authorities which were looking to adopt the model. Cambridgeshire County Council, for example, between December 2010 and January 2013 paid Morning Lane Associates $£ 474,750$ for assistance in introducing the 'Hackney model' in Cambridgeshire (Cambridgeshire County Council, 2013).

In 2013 Trowler resigned as director of the 'Morning Lane Associates' company when she was appointed as the government's chief social worker for children. When concerns were expressed about opening up children's social work and child protection services to the market place and the private sector Trowler tweeted that those who opposed opening up child protection and children's social work to the private sector were "like living in Animal Farm. 4 legs good. 2 legs bad" (Trowler, 2014b) and, in a piece headed 'Chief social worker defends government's new outsourcing laws', wrote:

"Their [government ministers] views and mine is that no sector - public, private or voluntary -has a monopoly of ideas or creativity or talent. This is precisely why they wish to provide more freedoms for those sectors to work together, harnessing the capacity of those with an interest in improving the lives of children" (Trowler, 2014a).

Trowler and Wood are members of the five person 'programme investment board' which has the brief to "provide rigorous advice to the Minister on what projects the Department [DfE] should invest in [through the government-funded Children's Social Care innovation Programme]" (Spring Consortium, 2014). The three other board members are from the financial sector, investing in and managing hedge and investment funds. In $2014 £ 400,000$ was awarded from the Innovation Fund to Morning Lane Associates (and five partner councils) to promote 'reclaiming social work'.

The board chairman of the Innovation Fund is Clive Cowdery, who is described as "founder of The Resolution Group, a financial services investor which has specialised in sponsoring insurance vehicles" (Spring Consortium, 2014). In an article entitled 'Children's services innovation is not about privatisation' he wrote:

"We want ideas from everyone: local authorities, social enterprises, companies and not-forprofit bodies ... This is not about privatisation. We are not here to sell our most vulnerable children to the highest bidder. We are here to give them - and the people who are most dedicated to helping them - a fighting chance" (Cowdery, 2014). 
'Spring Consortium', the body which manages the Children's Social Care Innovation Fund, comprises Deloitte (which provides "audit, consulting, financial advisory, risk management, tax, and related services"), the Innovation Unit ("an independent social enterprise"), and Mutual Ventures (which "led" on the outsourcing from local councils of 'Achieving for Children' in Richmond and Kingston and 'Evolve YP' in Staffordshire). 'Achieving for Children' has received $£ 500,000$ from the government's children's services innovation fund.

Another key government advisor on children's social services is Lord Warner. A former civil servant and director of social services, he was appointed to the House of Lords and became a health minister from 2003 to 2007 in the Labour government. In 2013 he wrote an article entitled 'Why I, a Labour peer, am supporting a regulated market for NHS competition' (Warner, 2013) at a time when Labour was opposing the opening up of NHS services to the market place. He had reported that he had been an advisor to private health care companies (see, for example, Public Administration Committee, 2008; Hansard, 2009). In June 2014 he was appointed by the government as "Commissioner in relation to Birmingham City Council, with responsibility for Children's Social Care” (Timpson, 2014) following a report and recommendations by Le Grand with Wood and Trowler (Le Grand, 2014).

\section{PARLIAMENTARY AND PARALLEL PROCESSES AND PROGRESS}

In June 2014, soon after the end of the government consultation period about the draft delegation regulation, it is reported that Meg Munn, chair of the All Parliamentary Group (APPG) on child protection, had:

"urged the government to think again over its proposals to permit the outsourcing of children's services, and to make abuse investigations exempt from the plans ... Munn went on to warn that "there is a big difference between providing therapeutic services to children and being responsible for the investigation of suspected child abuse". Echoing fears voiced by academics and other senior social work professionals, she expressed concerns that outsourcing child protection work, while leaving local authorities with ultimate responsibility for its quality, would "exacerbate risks" to young people by unnecessarily adding "another layer of accountability, monitoring and checking" (Turner, 2014b).

Meg Munn is qualified social worker. She was an Assistant Director of York City Council's Children's Services from 1999-2000 before becoming an MP, and was a government minister from 2005 to 2008.

In September 2014 Munn wrote:

"Other more complex issues were not widely considered [through the government's consultation], such as independent organisations intruding into family life, and the question of data sharing between public, private and third sector organisations. The full implications of these changes to the most sensitive areas of children's services have not been explored. While many children's services are provided by charities, it would be a significant change to let them undertake child protection investigations and assessments and seek court orders to remove children from families ... An outsourced, fragmented system with long lines of accountability will put children at risk" (Munn, 2014).

Munn made these comments in September 2014 at the time a House of Commons committee was considering the government's intentions to open children's social work services to the market place. Labour's leading spokesperson at the committee was Steve McCabe, who was a Labour whip. Steve McCabe is also a qualified social worker. At the committee meeting he said:

"If people's worse fears are realised and these measures prove to be the route to fragmentation, unaccountable, unregulated provision, riddled with conflicts of interest and 
dubious financial incentives, a future Government will have to repeal them. By that time, however, thousands of children might have suffered needlessly" (McCabe, 2014).

One of the reasons Labour seemed to be relatively sanguine about, and did not oppose, what the coalition government was intending was that the regulatory change was only enabling, not requiring, that local authorities contract out their children's social work services, including child protection McCabe, 2015). But why even give this power to councils if it was seen to make children more vulnerable and services less accountable? Why take this risk?

Neither has the Parliamentary Education (and Children's) Select Committee, which has the role of scrutinising government actions, sought to hold hearings about the radical and fundamental changes being driven forward for children's social work services and child protection, despite the Committee's clerk and professional advisor each being contacted in summer 2014 to ask that the Select Committee scrutinise what the government was proposing.

Whilst there was limited Parliamentary consideration of the proposed change in regulation, the DfE were already moving ahead with preparations to create a market for children's social (work) services. An invitation-only seminar was commissioned by the DfE. It was chaired by Lord Warner and organised by three companies of market and management consultants, and attended by, amongst others, Virgin Care and Amey (the construction company). A report on the seminar noted that:

"The proposals, which would radically shake up children's social services in England, put flesh on the bone of Coalition plans floated in the summer to inject "competition and contestability" into one of the last areas of local government not subject to market forces. They include the creation of new bodies independent of council control which would run children's social services across a local area and hold powers to outsource key functions to private firms and charities. These include sensitive decisions such as whether to take children away from their parents. The bodies - known as "newcos" - would be one of a series of measures designed to accelerate the growth of an independent child protection sector" (Butler, 2014c).

\section{WHY WOULD COUNCILS CONTRACT OUT STATUTORY RESPONSIBILITIES FOR VULNERABLE CHILDREN?}

As noted above, it has been argued (see Wood, quoted in Butler, 2014b) that private sector companies like G4S and Serco would not want the risk of taking the responsibility for child protection and other children's social work services. But this is not supported by their history to-date of bidding for and getting public service contracts.

For example, G4S already has had contracts for the tagging and supervision of offenders in the community. Serco has had contracts for out-of-hours GP services. ATOS was contracted by the government to undertake disability welfare benefits assessments. The performance of these commercial companies which largely make their profits out of government contracts has been a cause of considerable concern, with public money being inappropriately claimed by these companies and with services not being delivered (see Jones, 2014).

These private sector companies are not reluctant to move into children's health and social services. Virgin Care now has contracts for children's public health nursing, child and adolescent mental health services (CAMHS) and services for disabled children and their families. G4S and Serco share contracts for the forensic examinations of children who may have been sexually abused and G4S has also expanded into the provision of residential children's homes. Serco has already positioned itself throughout children's services - advising government; commissioning and managing for local authorities; providing children's services itself; and inspecting services for Ofsted (Serco, 2014). The suggestion that these big private sector companies, which have grown by gaining government contracts, are not interested in growing further through getting contracts for children's social services does not match their history or recent developments. 
But why would any local authority contract out crucial statutory responsibilities to private companies, or to any other organisation including voluntary agencies, when the local authority still held the accountability for these services and would be itself be rated (and berated!) by Ofsted for how well it fulfilled its statutory responsibilities? There are three reasons why council children's services might be contracted out and placed outside the management and control of the council.

First, some local authorities may take the view that the services will be better provided outside the public sector and local government, based on an ideological position that private sector good and public sector bad and that local government bureaucracy prevents the delivery of good children's social services. For example, as noted above Kingston and Richmond Councils have contracted their children's services to a community interest company (Kingston Council, 2014). But Ofsted reports that good children's social services are provided within local government (see, for example Ofsted, 2014). Local democracy, bureaucracy and accountability are not an inevitable hindrance.

Secondly, contracting out statutory children's services responsibility is being seen, as in Northamptonshire, as a response to central government funding cuts (Butler, 2014e). This is already generating concerns that children's services commissioners are contracting primarily on the basis of price and costs (Stevenson, 2014). Seeking to get statutory responsibilities met more cheaply is the inevitable consequence of central government dramatically reducing local government funding leading to service cuts at a time when workloads are increasing (see, for example, Dutta, 2014). The National Audit Office (2014) states that there will be a 37\% estimated real-terms reduction in government funding to local authorities between 2010-11 and 2015-16. This is at a time when between 2008 and 2014 child protection investigations have increased by $60 \%$ and child protection plans by $50 \%$ (based on Department for Education, 2014) and local authority care proceedings applications to the courts by $76 \%$ (based on CAFCASS, 2014) .

Whether it is seen as a 'double whammy' or a 'perfect storm', its impact is to make it very difficult for local authorities to consistently provide good children's social services. This is then used as an argument by government for 'innovation' and out-sourcing of these services. It is reinforced by Ofsted inspection standards having been heightened and terminology made harsher ('adequate' changed to 'requires improvement') and the government with its 'independent expert panel' (with no experience of providing or managing front-line child protection services) seeking that there be more serious case reviews, each published in full, when there is serious harm or death as a consequence of abuse or neglect and that these reviews should allocate accountability (blame) to agencies and workers (see, for example, HM Government, 2014; Department for Education, 2015). It all serves to prepare the ground for contracting out children's services and child protection from local authorities.

Thirdly, even if local authorities do not themselves look to contract out their children's social work services this can and is being required by central government, as in Doncaster (Butler, 2014d) and Slough (Puffet, 2014). Ofsted inspections and judgements are being used as the vehicle to allow local authorities to be targeted for out-sourcing despite concerns that Ofsted might be influenced by political and media pressures when making its judgements (LGA, 2014). Department for Education intervention teams and commissioners are being sent into local authorities with members such as Wood, Le Grand, Trowler and Warner who have been advocates for out-sourcing and opening up children's social work services to the private sector. In Rochdale, where Malcolm Newsam was appointed by the government as the commissioner for children's services (see below), an interim director of children's services has been recruited with a professional background, prior to senior management roles within children's services, in finance and accountancy (Pidd, 2014).

It is also intended that what was previously promoted by the Local Government Association as sectorled improvement for children's services is also to be opened up to the market place (Peters, 2014), with an influx of management consultants, with no necessary background in children's social services or child protection, to advise government and local authorities. In December 2014, with very little publicity and with a deadline of only days, the DfE invited those who might be interested to tender to 
become 'expert advisors who will provide improvement support and challenge to local authorities who have underperforming children's social care services" (Department for Education, 2014b) to attend a seminar. Those attending included G4S, KPMG, Mouchel and Amey - the latter more easily recognised as having government contracts for construction and engineering works and, more recently, transporting prisoners to and from courts.

And this marketisation and privatisation of children's social work services and child protection is actively promoted by parts of the media. A Times newspaper editorial, focussed on children's social workers, on 16 January 2015 was headed "Reinventing Government: Councils have cut staff and then hired them back as 'temps' at great expense. The solution is to farm out services to charities and the private sector". It stated that:

"The future for local government could be as a much leaner broker for the local community, purchasing and underwriting services, than it is a provider. This would mean charities and the private sector being involved ... Lower public expenditure is both a necessity and a virtue that will require imaginative change" (The Times, 2015).

This Times editorial reflects the argument which has been made by the coalition government minister who has recently played a lead role on government strategy, Oliver Letwin, who wrote a book titled 'Privatising the World" (Letwin, 1988) while head of the international privatisation unit at Rothchild's merchant bank (Powerbase, 2014).

But it is not only the right-wing press which has been campaigning for political parties to be more engaged with the private sector. For example, in January 2015 the Fabian Society published a report which stated that:

"A Labour government is going to need all the help it can get to achieve its social mission and so needs business as an ally, not an enemy. Rather than seeing markets as needing regulation to prevent them being socially destructive, the left needs a greater focus on how they can be helped to create social good" (Wallis and Tinker, 2015).

The Times editorial and the Fabian report were published in the same week in January 2015 that Circle Holdings, a private health care company which received the first government contract to take over a NHS hospital, had decided to withdraw from the contract as it required too much investment, could not make a big enough profit, and was also about to be the subject of a damning inspection report (BBC, 2015). If the profit cannot be made there is no continuing commitment to the service. The same had happened previously with Southern Cross, a company which provided care homes for older people, which after asset stripping by its international venture capital owners no longer became a profit-generating business and the owners withdrew from the providing the services (Anderson, 2011; Scourfield, 2012)). In each instance it was (as with G4S's failure to provide adequate security at the London Olympics) the public sector which had to provide a solution to the private sector failings and withdrawal.

Specifically in relation to children's social services being made vulnerable by profit seeking and taking there is the experience of children in children's homes owned by a private equity company:

"In the autumn of 2004 the private equity firm ECI made the following boast in its business review: 'Due to the excellent performance of the Sedgemoor business since ECI's initial investment in 2000, an opportunity arose to refinance the business and for ECI to get cash out.'

The newsletter flagged the refinancing of three businesses - Sedgemoor, debt management firm Gregory Pennington and restaurant group Tragus, triggering a $£ 20 \mathrm{~m}$ payout to its investors and partners. Fast forward three years, however, and it is a different story. Sedgemoor has gone into administration and is unlikely to be mentioned in despatches. 
If Sedgemoor was a widget factory, its demise might be described as mere bad luck. But it was one of the UK's largest residential care businesses looking after vulnerable children, and its financial difficulties caused more heartache than just fears about redundancies" (Wood, 2007).

Despite this and other experiences, children's social services were now seen as an 'industry' rather than a service, and as an increasing opportunity to generate profit, with market analysts and advisors promoting children's social services as growth opportunity for the private sector. Mintel, a company which describes itself as providing a range of market information, stated in a report titled 'Children's Social Care (Industrial Report) UK':

"Children's social care continues to be challenged by a number of high profile revelations in the courts, increasing media attention and pressure on politicians and local authorities to analyse arrangements. Independent provision of services is being significantly increased, but the need for further profound changes in the structure of provision has been acknowledged by the government" (Mintel, 2014).

Within Parliament the debate has moved on. The regulation allowing local authorities to outsource their children's social work services, including child protection investigations, assessments and subsequent actions, is now in force. There has been no major Parliamentary debate of vote on the regulation. There is no commitment from Labour to repeal it. There has been no scrutiny by the Education (and Children's) Select Committee of this radical regulatory change. Instead, in the House of Lords (House of Lords, 2014) rather than the House of Commons, the debate turned to the government's intention that the organisations contracted to provide children's social work and child protection services should not be regulated, required to registered, or inspected:

"The Government propose that the external providers of social work services will not be inspected in their own right by Ofsted, and nor will they be registered as providers in the way that children's homes and adoption societies are. There will be no overview of their activities across local authorities where they hold contracts and no visible assurances for the public about their financial viability, quality standards or working practices ... The drivers of service provision will be cost driven ... Regulations should not be regarded as a burden in this extremely sensitive area" (Donaghy, 2014).

Despite the concerns raised in the House of Lords, Labour again did not force a vote on the government's de-regulation intentions, with the deregulation now in 2015 in place. But why would any government want to leave crucial children's social work and child protection services unregulated, unregistered and uninspected? Possibly placing requirements and nationally determined standards on these services might be a deterrent when building a market, and add costs to organisations which might want to profit from the market now being created.

\section{CONCLUDING COMMENTS}

In the Victoria Clmbie Inquiry report (Laming, 2003) stress was placed on the clear allocation of political and managerial responsibility and accountability for the safety and welfare. This became a requirement in the 2004 Children Act, so that "between them, the Director of Children's Services and Lead Member for Children Services provide a clear and unambiguous line of local accountability" (HM Government, 2013c).

The experience of local authorities which have not been performing well in protecting children has been seen as directly related to inadequate political governance and managerial leadership and with councils not taking 'a whole council approach' to the welfare and safety of children. This was made clear in a presentation given to prospective 'social care advisors' at the December 2014 Department for Education seminar by Rotherham's government-appointed children's services commissioner (Newsam, 2014).

It is all the more surprising, therefore, that in opposition to previous inquiry reports, statutory requirements and current wisdom, the government has moved ahead with the marketisation of 
children's social work services allowing child protection investigations, assessments and decisions about the protection of children, and where they should live, to be contracted to unregulated, unregistered and uninspected organisations. This undermines accountability, and adds complexity and fragmentation, within the arrangements to secure children's well-being and safety.

No other country contracts out these crucial responsibilities for investigating child abuse and taking crucial decisions about the safety and welfare of vulnerable children, not even the radical right wing states of Kansas and Florida (Myslewicz, 2010). This would be disruptive and damaging even if these services were contracted out to not-for-profit organisations, but in England they can be contracted to profit-driven companies. The cloak of 'innovation' is a Trojan horse opening up a new market for companies like G4S, Serco, Virgin Care and others. It represents the end game for publicly provided children's social services and child protection and opens the door to profit-motivated intrusion within families.

\section{REFERENCES}

38 Degrees (2015) 77,000 of us got behind Children England and stopped the Government privatising child protection services, action@38degrees.org.uk.

ADCS (2014) ADCS response to the consultation on powers to delegate children's social care functions

http://adcs.org.uk/download/consultation-

responses/2014/ADCS consultation reponse on powers to delegate childrens social care functio ns.pdf.

Ahmed, M. (2007) Le Grand plan for GP-style social services practices, http://www.communitycare.co.uk/2007/07/04/le-grand-plan-for-gp-style-social-services-practices/.

Alexander, D. (2105) Alexander claims Tory cuts would lead to Dickensian future, The Guardian, 14 January, p 13.

Anderson, R. (2011), Southern Cross care homes: Landlords offer last hope , 2 June, http://www.bbc.co.uk/news/business-13615190.

Barber, M. (2007) Instruction to Deliver: Fighting to Transform Britain's Public Services, Methuen, London.

BBC (2015) Hinchingbrooke Hospital: Circle to withdraw from contract, http://www.bbc.co.uk/news/uk-england-cambridgeshire-30740956?print=true.

Butler, P. (2014a) Child social services for sale: Experts denounce Gove proposal to outsource children's protection to private firms, The Guardian, 17 May, $\mathrm{p} 1$ and $\mathrm{p} 4$.

Butler, P. (2014b) How Alan Wood became the 'go-to-fixer' for child protection, http://www.theguardian.com/society/2014/jul/09/alan-wood-go-to-fixer-child-protection-hackneysocial-work.

Butler, P. (2014c) Outsourcing: government advisors finesse child protection 'sales pitch', 29 October, http://www.theguardian.com/society/patrick-butler-cuts-blog/2014/oct/29/governementadvisors-finesse-child-protection-outsourcing-plans-market.

Butler. P. (2014d) Doncaster launches independent child protection company, 1 October, http://www.theguardian.com/society/2014/oct/01/doncaster-child-protection-company-launched. 
Butler, P. (2014e) Almost like a PLC: Northamptonshire sees the future of local government now, 18 December, http://www.theguardian.com/society/2014/dec/18/like-plc-northamptonshire-localgovernment-funding-cuts-council.

CAFCASS (2014) National picture of care applications in England for 2013-14, https://www.cafcass.gov.uk/news/2014/may/national-picture-of-care-applications-in-england-for2013-14.aspx.

Cambridgeshire County Council (2013) Response to Request for Information re: Morning Lane Associates, 29 January, Cambridge County Council.

Cardy, C. (2010) 'Care Matters' and the privatisation of looked after children's services in England and Wales: Developing a critique of independent 'social work practices', Critical Social Policy, 30(3): 430-442.

Cleary, J. (2014) Praise for Delegated Powers Rethink, Social Work Matters, The College of Social Work, p 12.

Cowdery, C. (2014) Children's services innovation is not about privatisation, http://www.theguardian.com/social-care-network/2014/jun/19/childrens-services-innovationprivatisation.

Department for Education and Skills (2006) Care Matters: Transforming the Lives of Children and Young People in Care, https://www.education.gov.uk/consultations/downloadableDocs/6731-DfESCare\%20Matters.pdf.

Department for Education (2014a) Characteristics of Children in Need, https://www.gov.uk/government/statistics/characteristics-of-children-in-need-2013-to-2014.

Department for Education (2014b) Children's Services Intervention Experts, 2 December, http://www.government-online.net/childrens-services-intervention-experts-department-education/.

Department for Education (2015) Revisions to working together to safeguard children Government consultation, https://www.gov.uk/government/uploads/system/uploads/attachment_data/file/392987/Working_Toge ther To Safeguard Children- Consultation Document.pdf.

Donaghy, Baroness (2014) Deregulation Bill (clause 71: reduction in regulation of providers of social work services), Grand Committee, House of Lords, Tuesday, 18 November 2014. Deregulation Bill, http://www.publications.parliament.uk/pa/ld201415/ldhansrd/text/141118-gc0001.htm.

Dutta,K, (2014) Social work budget cuts are putting children at risk, says NSPCC 31 March, http://www.independent.co.uk/news/uk/home-news/social-work-budget-cutsare-putting-children-atrisk-says-nspcc-9224796.html.

Garrett, P.M. (2008) Social Work Practices: silences and elisions in the plan to 'transform' the lives of children 'looked after' in England, Child and Family Social Work, 13(3): 311-318.

Garrett, P.M. (2009) Transforming children's services?: social work, neoliberalism and the modern world, McGraw-Hill Open University Press, Maidenhead.

Garrett, P.M. (2010) Creating Happier Children and More Fulfilled Social Workers: Neoliberalism, Privatisation and the Reframing of Leftist Critiques in Britain, Journal of Progressive Human Services, 21(1): 83-101.

Garret, P.M. (2105) 'Introducing Michael Gove to Loic Wacquant': Why Social Work Needs Critical Sociology, British Journal of Social Work, published on line 14 April, DOI: 10.1093/bjsw/bcv024. 
Giddens, A. (1998) The Third Way: The Renewal of Social Democracy, Polity Press, Cambridge. Goodman, S. and Trowler, I. (2011) Social Work Reclaimed: Innovative Frameworks for Child and Family Social Work Practice, Jessica Kingsley, London.

Hansard (2009) Column 656, 6 May, http://www.publications.parliament.uk/pa/ld200809/ldhansrd/text/90506-0016.htm\#09050716000016.

Hayes, D. (2013) U-turn on regulation of independent social work providers, http://www.cypnow.co.uk/print_article/cyp/news/1078423/u-regulation-independent-socialproviders?print=true.

Haris, J. (2005) The Social Work Business, Routledge, Abingdon,

Hayes, D. (2014a) New Barnardo's chief eyes strategic role in children's services, http://www.cypnow.co.uk/cyp/news/1144007/barnardos-chief-eyes-strategic-role-childrens-services.

Hayes, D. (2014b) Narey defends private sector role in child protection, http://www.cypnow.co.uk/cyp/news/1144301/narey-defends-private-sector-role-child-protection.

HM Government (2013a) Providers of Social Work Services (England) Regulations, http://www.legislation.gov.uk/uksi/2013/2668/pdfs/uksi_20132668_en.pdf.

HM Government (2013b) Changes to social work regulation and inspection, Ofsted, https://www.gov.uk/government/news/changes-to-social-work-regulation-and-inspection.

HM Government (2103c) Statutory guidance on the roles and responsibilities of the Director of Children's Services and the Lead Member for Children's Services : For local authorities, April, https://www.gov.uk/government/uploads/system/uploads/attachment data/file/271429/directors of c hild_services___stat_guidance.pdf.

HM Government (2014) First annual report: National panel of independent experts on serious case reviews,https://www.gov.uk/government/uploads/system/uploads/attachment data/file/338058/First a nnual_report__national_panel_of_independent_experts_on_serious_case_reviews.pdf.

House of Lords (2014) Deregulation Bill (clause 71: reduction in regulation of providers of social work services), Grand Committee, Tuesday, 18 November, http://www.publications.parliament.uk/pa/ld201415/ldhansrd/text/141118-gc0001.htm.

Jones, O. (2014) The Establishment: And How They Got Away With It, Allen Lane, London.

Kingston Council (2014) How we deliver our services: Achieving for Children, http://www.kingston.gov.uk/info/200268/coordinating_childrens_services/815/how_we_deliver_our_ services.

Laming, H. (2003) The Victoria Climbie Inquiry, https://www.gov.uk/government/uploads/system/uploads/attachment_data/file/273183/5730.pdf.

Le Grand, J. (2007) Consistent Care Matters: Exploring the Potential of Social Work Practices, http://dera.ioe.ac.uk/7645/1/DFES-00526-2007.pdf.

LGA (2014) Ofsted review is needed to renew confidence, Local Government Association First, 8 November. 
Le Grand (2003) Motivation, Agency and Public Policy: Of Knights and Knaves, Pawns and Queens, Oxford University Press, Oxford.

Le Grand, J. (2014) Report to the Secretary of State for Education and the Minister for Children and Families on ways forward for children's social care services in Birmingham, https://www.gov.uk/government/uploads/system/uploads/attachment data/file/297748/Birmingham r eport_25.03.14.pdf.

Letwin, O. (1988) Privatising the World: A Study of International Privatisation in Theory and Practice, Cassell, London.

Manthorpe, J., Harris, J., Hussein, S., Cornes, M. and Moriarty, J. (2014) Evaluation of Social Work Practices with Adults: Summary Report, http://www.kcl.ac.uk/sspp/policy-

institute/scwru/pubs/2014/reports/Social-Work-Practices-w-Adults-SUMMARY-REPORT-2014.pdf

McCabe, S. (2014)

http://www.publications.parliament.uk/pa/cm201415/cmgeneral/deleg4/140903/140903s01.htm

McCabe, S. (2015) @steve_mccabe, 7 January.

McCardle, L. (2014) Ofsted to shift children's centre inspections from providers to councils, http://www.cypnow.co.uk/cyp/news/1144903/ofsted-shift-childrens-centre-inspections-providerscouncils.

Meek, J. (2014) Private Island: Why Britain Belongs to Someone Else, Verso, London.

Mintel (2014) Children's Social Care (Industrial Report) - UK - May 2014, http://reports.mintel.com/display/691836/.

Munn, M. (2014) Plans to allow outsourcing of child protection will put young people at risk, http://www.theguardian.com/society/2014/sep/02/outsource-child-protection-young-people-riskrotherham.

Myslewicz, M. (2010) An Analysis of the Kansas and Florida Privatisation Initiatives, Casey Family Programs, Seattle.

National Audit Office (2014) The impact of funding reductions on local authorities, http://www.nao.org.uk/wp-content/uploads/2014/11/Impact-of-funding-reductions-on-localauthorities-Executive-Summary.pdf.

Newsam, M. (2014) Children's Social Care Services -Advice, Support and Challenge: Supplier Day, 17 December, unpublished.

Office for Budget Responsibility (2014) Economic and Fiscal Outlook December 2014, http://cdn.budgetresponsibility.independent.gov.uk/December 2014 EFO-web513.pdf.

Ofsted (2014) Hampshire County Council: Inspection of services for children in need of help and protection, children looked after and care leavers and Review of the effectiveness of the local safeguarding children board, http://reports.ofsted.gov.uk/sites/default/files/documents/local_authority_reports/hampshire/051Single \%20inspection\%20of\%20LA\%20children's\%20services\%20and\%20review\%20of\%20the \%20LSCB \%20as\%20pdf.pdf.

Peters, D. (2014) Axe fears over top-slice, 12 December, Municipal Journal, p. 1. 
Pidd, H. (2014) Incoming Rotherham children's chief: 'It's the most difficult job in Britain', 17 December, http://www.theguardian.com/society/2014/dec/17/ian-thomas-rotherham-childrensservices-sexual-abuse-difficult-job.

Powerbase (2014) http://powerbase.info/index.php/Oliver Letwin.

Public Adminstration Committee (2008) 8 May, http://www.publications.parliament.uk/pa/cm200809/cmselect/cmpubadm/36/8050804.htm.

Puffet, N. (2014) Timpson strips Slough of responsibility for children's services, 24 April, http://www.cypnow.co.uk/cyp/news/1143657/timpson-strips-slough-responsibility-childrensservices\#sthash.5jg0rhBs.dpuf.

Scourfield, P. (2012) Caretelisation revisited and the lessons of Southern Cross, Critical Social Policy, 32(1):137-148.

Serco (2014) http://www.serco.com/markets/education/about_us.asp.

Spring Consortium (2014) http://springconsortium.com/.

Stanley,N., Austerberry, H., Bilson, A., Farrelly, N., Hargreaves, K., Hollingworth, K., Hussein, S., Ingold, A., Larkins, C., Manthorpe. J., Ridge, J. and Strange, V. (2012) Social Work Practices: Report of the National Evaluation,

https://www.gov.uk/government/uploads/system/uploads/attachment_data/file/183309/DFE-

$\underline{\text { RR233.pdf }}$

Stevenson, L. (2014) Children's outcomes 'compromised' as commissioners focus on balanced budgets', 25 November, http://www.communitycare.co.uk/2014/11/25/childrens-outcomescompromised-commissioners-focus-balancing-budgets/.

The Times (2015) Reinventing Government, 14 January, p 28,

Timpson, E. (2014) Letter to Lord Warner, https://www.gov.uk/government/uploads/system/uploads/attachment data/file/319390/Letter to Lord Warner_-_06.06.2014.pdf.

Trowler, I. (2014a) Chief social worker defends government's controversial new outsourcing laws, http://www.communitycare.co.uk/2014/06/26/chief-social-worker-defends-governmentscontroversial-new-outsourcing-laws/.

Trowler, I. (2014b) @IsabelleTrowler Jun 30.

Turner, A. (2014a) 10 key arguments from the consultation on children's social work outsourcing, http://www.communitycare.co.uk/2014/06/09/10-key-arguments-consultation-outsourcing-childrenssocial-work/.

Turner, A. (2014b) Cross-party group calls for rethink over child protection outsourcing, http://www.communitycare.co.uk/2014/06/25/cross-party-group-calls-rethink-child-protectionoutsourcing-plans/.

Wallis, E. and Tinker, R. (2105) In It Together: Labour's new relationship with business, 16 January, http://www.fabians.org.uk/in-it-together-2/. 
Wood, Z. (2007) Should profit come before children?, 21 October,

http://www.theguardian.com/business/2007/oct/21/observerbusiness.businessandmedia13.

7933 words 